\title{
About the Potential of E-democracy in Cooperative Organisations
}

\author{
J osé Monserrat Neto
}

\author{
Computer Science Departament - DCC \\ Federal University of Lavras - UFLA \\ Lavras - MG - Brazil \\ E-mail: monserrat@dcc.ufla.br \\ Tel: 553538291545
}

\begin{abstract}
This paper develops a reflection on the potential of e-democracy to strengthen society's democratization exploring historically and technically the possibilities of cooperative organisations. From Singer's historical view about the rise of capitalism it is conjectured that Internet and e-democracy could be the technological innovations capable to trigger off the creation of a virtual network of
\end{abstract}

\author{
cooperative organisations and thereby the development of \\ a new economic system, based more on humanitarian \\ values than the present ones. \\ Keywords: e-democracy, cooperation, social emancipation \\ Acknowledgement: the cooperative people of all over the wolrd
}

\section{Introduction}

The fast growing of the Internet does not surprise any more and by now it is used in all areas of society. Inside companies and organisations in general it has opened up a wide range of possibilities for people to work at a distance. The world has become smaller with people being closer to each other (Castells, 2001; Sorj, 2003; Santos, 2003). Recently, the Internet has been used in governmental services, for instance, in Brazil on a large scale federal tax declarations are elaborated and delivered via the Internet and public elections are realized with the help of electronic ballot boxes.

This paper proposes a reflection on the potential of e-democracy in order to strengthen society's democratization by trying to identify its future alternatives. The starting point is Singer's interpretation of the rise of the capitalist system (Singer, 1996). He argues that capitalism managed to surpass feudalism when capitalist proto-enterprises developed manufacturing machines which allowed them to prevail over craft workshops and thereby starting the formation of the capitalist society. I conjecture the possibility of the Internet having a similar role in the emergence of a new production system based on a cooperative and democratic network

\section{Historical contextualization}

In his analysis of structural unemployment induced by the computer revolution Singer proposes the expansion of cooperatives as a way to overcome unemployment and capitalism itself (Singer, 1996). In order to develop this idea the author examines England in the XVIII century when capitalism hardly put itself as an alternative to the feudal system. 
Singer redefines the term 'revolution' to be understood as in two interconnected though distinct levels: the 'social' one in which social and economic processes occur gradually and the 'political' one in which 'revolution' means a fast, sometimes violent change of the political structures. In this way the 'capitalist social revolution' is distinguished from the 'capitalist political revolution'. The 'social' revolution encompasses the changes of the English economy which gradually transform into a capitalist system with the increasing use of new machines, the competition with "closed markets" of the craft workshops and the waging process of peasants and craft workers themselves. On the other hand the 'political' revolution involves institutional changes intended to alter quickly governmental structures; the English revolution of 1668 and the French revolution in 1789 are examples of political revolutions. The above mentioned changes would break down resistences against the economic and social transformations which were occurring for a long time in those countries, that is, the expansion of capitalism. Thus capitalism has arisen from the interstices of feudalism (in the country) and of craft workshops (in the city), both supported by the noble power and the feudal lords, and has not arisen from a 'bourgeois' revolution. The author suggests the creation of a new production system be born from the interstices of capitalism and not from a 'proletarian' revolution.

The socialist 'social' revolution covers social advances obtained by workers in capitalism, such as trade union representation, universal suffrage, labour and social welfare legislations, and several forms of civil and cooperative organisations. For Singer the cooperative is the most promissing form of organisation to be explored in order to create a new mode of production. To examine this possibility, he compares the situation of the capitalist proto-enterprises with that of the current cooperatives.

For a long time capitalist proto-enterprises cohabited with the craft production of master workshops and fought against the free market impediments held by craft workshops and by the feudal system. Technological innovations finally made the difference. Inventions such as the sewing machine, 'jeanny', etc, were developed in those new enterprises (Donald \& Wajcman, 1985). Nevertheless, the first inventions were also used by craft workshops, allowing a certain balance with the new manufacturing enterprises. When, however, the innovations demanded a huge amount of financial resources, the capitalist manufacturing system of production had a decisive competitive advantage over the craft one. Inventions like 'water-frames', 'stream engine', 'loom machine', etc, could be afforded only by capitalist enterprises which operated through shares, accumulated capital and employed large numbers of workers. The new situation led to the rise of factory production and capitalism.

To identify the competitive advantage of cooperatives over enterprises Singer examines the first cooperatives. The unemployed craft workers had two alternatives: either they got employed in the emergent capitalist factories or they organized each other in the form of cooperatives. Within certain limits cooperatives managed to compete with enterprises and some were relatively sucessful, such as the Rochild Society in England. Nowadays with the increasing unemployment due to informatics and the crises of capitalism cooperatives appear to be again an option for unemployed workers. After a careful analysis Singer concludes that the competitive advantage of cooperative consists above all in its democratic, self-reflexive and unalienating form of working, and therefore making the individual's and collective's realization possible in a more accomplished way. The cooperative would be the most distant option from the competitive, anti-social and alienating logic of the capitalist market. However, cooperatives have often been failing. They debilitate due to desertion of their members, bureaucratizing processes or, when assimilated into the market logic, they transform themselves into traditional companies. In short, they have been unable to compete effectively with traditional enterprises. Yet in order to become an economic alternative and a viable way to social emancipation they have to surpass capitalist companies. Singer finally draws attention to the point that cooperatives do not create a new production mode like 
capitalist enterprises did with the advent of great manufacturing machines. Therefore he suggests to search to improve cooperatives and to reinforce democracy inside institutions under capitalism.

\section{Internet as a decisive advantage for cooperative organisations?}

Singer's approach stimulates reflections on the potential of e-democracy. Perhaps the Internet is the technological innovation capable to create the decisive competitive advantage to open up a way for a new production system. It allows the free flow of data, democratization of the access to information and cooperative work at a distance at an unprecedented level worldwide, possibly so radical as were the first manufacturing machines of the XVIII century. The Internet is a medium that is based on a decentralized networked structure that allows many-to-many communication, interaction, and real-time communication which bridges close together spatio-temporal distances (Fuchs, 2003a). Would not the Internet and edemocracy be a technological invention subject to be fully explored only by organisations of definetely cooperative and democratic character?

This hypothesis is based on four reasons:

1) Human history proves that its course is often unpredictable. Who would foresee in the 60s of the $X X$ century that computers would become a sort of household appliance? We ought to be open minded for the creation of new alternatives for the future society.

2) We experience a serious civilization crisis which has an economic basis but goes beyond. It is a crisis of values, of identity and of project. Society shows itself incapable of solving old and new problems, such as employment, famine, poverty, housing, pollution, health, peace, security, environmental and natural resources' preservation, sustainable development, etc. It is incapable to offer perspectives and hope to the people. Nevertheless, there is a strong political desire, expressed, for instance, by the initiatives of United Nation Organization and World Social Forum, to change the current course to selfdestruction of society.

3) There is a great potential for cooperative actions with the help of Internet technologies. For instance, in the interstices of capitalist software industry a network of programmers and small enterprises has emerged which functions in a cooperative way. The success of 'Linux' developed by independent programmers spread out all over the world is undoubtedly due to cooperative work realised via Internet. It is amazing how they are able to compete with Microsoft's billions of money. On a social and political level there are several cases for the use of e-democracy and of initiatives organised, published and mobilized via Internet. Discussion lists of organisations are a simple and effective form of e-democracy. Some of them are national, like the Brazilian Computer Society (SBC). In Brazil strikes of lecturers are organised and mobilized via Internet and there is the inspection of enterprises and governmental services (some as E-government) made by citzens and innumerable social and political initiatives of diverse civil and nongovernmental organisations. In 2002 an American organisation "MoveOn.org - Democracy in Action" led an international political movement for peace against the war of the United States with Iraq via Internet.

4) The potential of the cooperative model of production, despite impasses of current cooperatives, offers an alternative for workers with regard to the employment issue and as a possible way to social emancipation.

However, it should be stressed here that cooperation principles have acquired a quite ambigious character in capitalism. Although Internet and e-democracy tools may enhance the potential for democratic and participatory cooperation, as argued above, at the same time they do extend competition, 
exploitation and alienation. Capitalist enterprises make use of cooperation (team work, computer supported cooperative work (CSCW), participatory management as a new ideology of management, cooperation between sub-units of a globally distributed firm, the networked enterprise, etc.) in order to advance competition and monopolization. Hence the actual character of cooperation today is antagonistic (Fuchs, 2003b). Cooperation is currently used to advance a flexible regime of capitalist accumulation which aggravates social problems, and, on the other hand, advances the socialization of production which in turn may pose a promissing potential for a fully cooperative and democratic society.

\section{E-democracy in a virtual network of cooperative organisations?}

The cooperative experience of Mondragón, in Spain, provides a rich insight here. It is not a cooperative, is a network of cooperatives, relatively autonomous, organised as a client-supplier system. What they do not acquire in the network itself they get from the government and enterprises. Each autonomous unit is relatively small and capable to maintain the cooperativism principles. In this way the "cooperative" of Mondragón avoids bureaucratization and alienation to a large extent (Souza Santos, 2002).

This exemplary case among many others are still to be further examined more profoundly. But it already allow us to glimpse an initial conclusion: in order to be really successful the cooperative logic must go beyond the own cooperative borders. Outside the cooperative should exist other cooperative organisations which follow the same cooperative principles. In short, cooperatives will not be successful if they work in isolation from each other. They need to form a network of cooperative organisations which works equally in a cooperative way. In this point, the huge potential of Internet and e-democracy comes out and allows us to speculate about the actual possibility of the formation of such networks by means of which cooperatives could reinforce reciprocally as well as with regard to the internal production and management as to the external relationships. The e-democracy and e-(cooperative work) tools would be essential to turn feasible these virtual networks of cooperative organisations.

Possible objection: Even though national and world networks of cooperatives are capable to compete with traditional enterprises they do not necessarily rule out the global logic of market competition and they are still subject to transform themselves sooner or later into capitalist enterprises. Right, but perhaps the cooperatives could share means of production, not the physical machines, but the production techniques (including know-how), the knowledge about production. If this was viable in some way it would hit directly the heart of the current competition logic. We all know that new technologies of production are the most valuable part of the production system with highly aggregated values. And if a virtual network could share such means of production and achieve to rule out private ownership, a central feature of capitalism, would it not trigger off the development of a new economic system?

Has this speculation exceeded all limits? Maybe not. The collective ownership of the means of production already occurs at least partially as the success of 'Linux' and 'Apache' shows in the industry of 'open source' and free software. The freedom of access to such software, at least to its code, is a form of collective ownership. It is free. Any person can alter and improve it. Besides, the production system of 'open source' allows the creation of more efficient and secure programs. Sharing source codes among programmers and users of a given program turns its development and improvement more efficient and quicker (Raymond, 2001). By and large, the result is a better program. Thus, there is a precedent which authorises us to examine the feasibility, theoretically and practically, of sharing the means of production in a virtual network of cooperative organisations. Moreover, there are computer simulations which explore the potential of cooperation in multi-agents system (Axelrod, 1997). Why not using them to study this crucial issue? 
Last objection: are the technological means - Internet and e-democracy tools - sufficient to turn viable a virtual network of cooperative organisations? I do not think so. The technological means do not substitute the need to cultivate and improve the principles of solidarity, cooperation, tolerance and democracy, the necessity of the civilising advance being committed to the primacy of public and humanitarian interests. The technological means just provide (or do not) opportunities to develop those principles. The crucial issue is the collective development of the culture of dialogue, tolerance, cooperation, democracy and common wealth in all spheres of social life. For this historical task initiatives from state, government, civil and political organisations - society in general - need to come close together and work in a constructive way. It is up to us to make good use of the technological opportunities opened up and develop cooperatively such an initiatives.

\section{Conclusion}

This reflection about the potential of e-democracy and Internet itself in order to reinforce democracy has focalized particularly on cooperative organizations. Starting from Singer's point of view about the rise of capitalism this paper has suggested the Internet as a possible technological means capable of pushing forward the development of a new economic system which would be based more on humanitarian values than the present ones. Surely this reflection has in no way the intention to offer a final solution, it is just a set of ideas to stimulate debates and to be further explored.

\section{References}

Sorj, Bernardo (2003) brasil@povo.com - a luta contra a desigualdade na sociedade da informação (brazil@people.com - the fight against inequality of information society). São Paulo. Editora Jorge Zahar.

Sousa Santos, Boaventura de (ed.) (2002) Produzir para Viver - os caminhos da produção não capitalista (Producing to Live - the ways of non-capitalist production). Rio de Janeiro. Editora Civilização Brasileira.

Fuchs, Christian (2003a) Globalization and Self-Organization in the Knowledge-Based Society. TripleC, Vol.1, No.2 http://triplec.uti.at/files/tripleC1(2)_Fuchs.pdf

Fuchs, Christian (2003b) Co-operation and Self-Organization. TripleC, Vol.1, No.1 http://triplec.uti.at/files/tripleC1(1)_Fuchs.pdf Mackenzie, D./Wajcman, J. (eds.) (1985) The Social Shaping of Technology. Open University Press, USA.

Raymond, Eric (2001) The Cathedral and the Bazaar. New York. O'Reilly \& Associates.

dos Santos, Laymert G. (2003) Politizar as Novas Tecnologias - o impacto sócio-técnico da informação digital e genética (To Politic the New Technologies - the socio-technical impacts of digital and genetic information). São Paulo. Editora 34.

Castells, Manuel (2001) The Internet Galaxy - reflections on the Internet, Business and Society. Oxford University Press.

Singer, Paulo (1996) Uma Utopia Militante: Repensando o Socialismo (A Militant Utopia: Rethinking Socialism). São Paulo. Editora Vozes.

Axelrod, Robert (1997) The Complexity of Cooperation. Princeton University Press. 